\title{
Effect of some pre-treatments on acrylamide concentration in potato chips
}

\author{
Khalaf H.H.A., Sharoba A.M., El-Desouky A.I., El-Bassiony K.R.A.", Afifi S.A.M.* \\ Food Sci. dep. - Fac. of Agric., Moshtohor, Benha Univ. \\ * Food irradiation unit-plant research dep.-Research Center, Atomic Energy Authority.
}

\begin{abstract}
This work was done to investigate the effect of some pretreatments, soaking in $(0.5,1,1.5$ and $2 \%)$ calcium chloride $\left(\mathrm{CaCl}_{2}\right)$ and Citric acid (for different times of soaking 30 and $60 \mathrm{~min}$.) on acrylamide formation in potato chips. The pretreated potatoes slices $0.2 \mathrm{~mm}$ were fried at the temperature degree $(185 \pm 5$ ${ }^{\circ} \mathrm{C}$ for 6-7 min) on an electrical fryer using palm oil. Generally, the untreated potato chips had higher acrylamide content than the soaked potato chips. The highest level of acrylamide was found in samples contained the highest reducing sugars; followed by those contained the moderate level of reducing sugars and the highest level of asparagine. While, the lowest level of acrylamide content was detected in samples contained the moderate level of reducing sugars and the lowest content of asparagine. Which maintain that reducing sugars and asparagine contents of samples before frying played an important role in acrylamide formation. Sensory characteristics could not be used as an indicator for acrylamide content, related to those potato chips with similar sensory characteristics had different acrylamide concentrations. The results of the present study suggest that acrylamide formation depended strongly on frying conditions (especially reusing of oil) and chemical composition of samples (especially reducing sugars and asparagine content). In the end, from those results using soaking in calcium chloride $2 \%$ and citric acid $1 \%$ for 60 min can reduce the formation of acrylamide.
\end{abstract}

Keywords: Acrylamide, aspragine, reducing sugar, potato chips, frying, palm oil, soaking, Cacl 2 , citric acid

\section{Introduction}

Acrylamide is a low molecular weight vinylic compound. This colorless and odorless crystalline substance is highly water soluble, easily reactive in air and rapidly polymerizable, i.e. single molecules of acrylamide (monomers) can bind together and form a larger molecule (polymer) with new properties (Besaratinia and Pfeifer, 2007). It was first reported in cooked foods in 2002 (Tareke et al., 2002).

Acrylamide is a potential health hazardous compound, occurring during preparation and/or processing of foods, although studies to date have not demonstrated carcinogenicity in humans. It is also a known neurotoxin. The toxicological studies on acrylamide revealed that, it causes DNA damage and at high doses, neurological and reproductive effects have been observed. The no observed effect level for acrylamide was reported to be up to $2 \mathrm{mg} / \mathrm{kg}$ rat body weight per day (FAO/WHO, 2002). Allan, (2002) reported that acrylamide is considered to be genotoxic in-vivo and carcinogenic in experimental animals. The acute oral $\mathrm{LD}_{50}$ for acrylamide in rats is $107-203 \mathrm{mg} / \mathrm{kg}$ body weight (Lindsay, 2002).

Olesen et al., (2008) reported that there was a positive association between acrylamide-hemoglobin levels and estrogen receptor positive breast cancer. On the other hand, epidemiological studies indicate that dietary acrylamide intake is not associated with other cancer risks, prostate cancer (Wilson et al., 2012), gastrointestinal cancer (Hogervorst et al.,
2008), bladder cancer (Mucci et al., 2003), thyroid cancer, brain cancer (Hogervorst et al., 2009a), and lung cancer (Hogervorst et al., 2009b).

Acrylamide was shown to be present in a wide range, from low levels in bread and meat products, too much higher levels in potato chips. Even this preliminary study showed that temperature and moisture content were key factors in the levels of acrylamide formation (Burch, 2007).

The Maillard reaction has been shown to generate acrylamide (Mottram et al., 2002 and Stadler et al., 2002), it is generally agreed that the main precursors are sugars and the amino acid asparagine (Amrein et al., 2003)

Potatoes contain relatively high amounts of sugars (glucose, fructose and sucrose) and asparagine. These components are varied with potato variety and storage conditions (Olsson et al., 2004, Wicklund et al., 2006).

Acrylamide has been found mainly in carbohydrate-rich foods and that in general the highest levels were found in potato crisps and chips (Becalski et al., 2003 and Yusa et al., 2006). Chemical analysis has shown that acrylamide is presented in a large number of foods and its level differ widely within each food group analyzed, despite it has so far not been detected in raw foods. For example, raw potato has negligible levels of acrylamide ( $<0.030 \mathrm{mg} / \mathrm{kg}$ of potato) but, if you make potato chips, the level of acrylamide can skyrocket to $1.2 \mathrm{mg} / \mathrm{kg}$ (Swedish National Food Administration, 2002). Acrylamide does not only 
form in industrially manufactured foods, but also foods prepared at home are concerned (Glese 2002).

Mottram et al., (2002) found that the acrylamide formed in significant quantities when the food was heated at about $180^{\circ} \mathrm{C}$.

The formation of acrylamide in fried foods was found to depend on the composition of raw materials and frying conditions. In potato chips, acrylamide was rapidly formed at over $160{ }^{\circ} \mathrm{C}$, the amount proportional to the heating duration and temperature (Kim et al., 2005).

Its formation pathway is linked with the Maillard reaction. The free amino acid asparagine and reducing sugars are considered as the main precursors (Stadler et al., 2004). A number of raw material pre-treatments were investigated which could mitigate acrylamide formation. These techniques include the extraction of acrylamide precursors by soaking or blanching in water or in acidic solutions (Kita et al., 2004; Pedreschi et al., 2004 and Pedreschi et al., 2007).

Use the organic acids, such as citric, acetic and L-lactic acid to reduce the final acrylamide content, but merely due to a reduced $\mathrm{pH}$ (Mestdagh et $\boldsymbol{a l}$., 2008). Calcium ions induced a supplementary acrylamide reduction, not attributed to a lower $\mathrm{pH}$. Previously, the mitigating effect at low $\mathrm{pH}$ was attributed to protonation of asparagine amino groups. This would block the nucleophilic addition of asparagine with a carbonyl compound, preventing the formation of the corresponding Schiff base, a key intermediate in the Maillard reaction and in the formation of acrylamide (Kita et al., 2004; Pedreschi et al., 2004 and Pedreschi et al., 2007). Also $\mathrm{Na}^{+}$or $\mathrm{Ca}^{2+}$ were indicated to interact with asparagine to prevent the formation of acrylamide (Park et al., 2005; Lindsay and Jang, 2005 and Gökmen and Senyuva, 2007). On the other hand, the addition of $\mathrm{NaCl}, \mathrm{CaCl}_{2}$ or citric acid might also change the oil uptake (Bunger et al., 2003; RimacBrncic et al., 2004 and Pedreschi et al., 2007).

Unfortunately above-mentioned treatments may also have an impact on the sensorial product quality, since low $\mathrm{pH}$ also suppresses the Maillard reaction, responsible for the generation of desirable flavours and colours. Acidification may moreover result in a sour product taste (Kita et al., 2004 and Franke $\boldsymbol{e t}$ al., 2005). This effect however depends upon the applied soaking or blanching treatment and the type and concentration of the acid used. It was suggested that acetic acid would be a better acidulant for the pre-treatment of potato crisps compared to citric acid, due to the less appearing sourness (Kita et al., 2004).

The present study aims to investigate the effect of different pretreatments (soaking in 0.5, 1, 1.5 and $2 \%$ Calcium chloride $\mathrm{CaCl}_{2}$ and Citric acid for different times, 30 and $60 \mathrm{~min}$ ) on the level of acrylamide in the produced potato chips.

\section{Materials and Methods}

\section{Materials:}

-Potatoes (Solanum tubersum), Hermes variety was obtained through 2014 from Agricultural Research Center, Ministry of Agriculture and Land Reclamation, Giza, Egypt.

- Palm oil was obtained from Arma Oil Company ${ }^{10}$ th of Ramadan city, Egypt.

- Citric acid and calcium chloride were obtained from El Gamhorea Pharmaceutical

Methods:

Technological methods:

Preparation of potato chips:

Potato tubers were hand washed in tape water for three min and hand peeled, then sliced using slicer machine at $2.0 \mathrm{~mm}$ thickness. Potato slices were washed again with tap water.

\section{Pretreatments:}

Prepared $\mathrm{CaCl}_{2}$ with concentrations ( 1 and $2 \%$ ) and citric acid with concentrations $(0.5$ and $1 \%)$ then soaking for (30 and $60 \mathrm{~min}$ ) for each concentration, after soaking peeled the slices for $10 \mathrm{~min}$.

Each sample were fryer in electrical frying using palm oil at $185 \pm 5^{\circ} \mathrm{C}$ for $6-7 \mathrm{~min}$.

\section{Chemical analysis methods Chemical composition:}

Moisture, crude protein, ether extract, ash and fiber of fresh and fried potato chips were determined according to the methods described in AOAC (2000). Total carbohydrates were calculated by difference.

Acid value, Peroxide value, Iodine value, Saponification values (AOAC, 1995). Refractive index: Refractive index of the oil was determined according to the AOAC (2000) using a refractometer (NYRL.3 Poland).

\section{Determination of reducing sugars:}

Total and reducing sugars were determined by Shaffer and Hartman method as described in the AOAC (2005) while nonreducing sugars were calculated by difference.

\section{Determination of aspragine:}

Asparagine was determined by a High Performance Liquid Chromatography analysis ((Shinadzu HPLC) according to the method described by Tcherkas et al. (2001) and Paramás $\boldsymbol{e t}$ al. (2006) in the National Research Center, Giza, Egypt.

\section{Determination of Acrylamide:}

Preparation of samples and extraction of acrylamide were performed in laboratory and determination was done using HPLC as following: 


\section{Extraction:}

Fifteen grams of samples (potato chips) were crushed in a Warring Blender. Five grams of the crushed sample were mixed with $50 \mathrm{ml}$ of distilled water. After shaking at $100 \mathrm{rpm}$ for $30 \mathrm{~min}$, the sample was centrifuged at $9000 \mathrm{rpm}$ at $4^{\circ} \mathrm{C}$ for 30 min. The supernatant was transferred into a $100 \mathrm{ml}$ separating funnel and allowed to stand for $20 \mathrm{~min}$ to allow the aqueous and lipid layer to separate. The aqueous layer was removed and used for determination of acrylamide (Vattem and Shetty, 2003).

\section{HPLC conditions:}

High Performance Liquid Chromatography (HPLC) with spectrophotometric detector (Shinadzu HPLC) was used for quantitative determination of acrylamide levels in the experimental foods under the following conditions: Column flow rate: $1 \mathrm{ml} / \mathrm{min}$. Wavelength: $230 \mathrm{~nm}$. Column temp: $25^{\circ} \mathrm{C}$. Iso cartic elution.

\section{Sensory analysis:}

Organoleptic evaluation of fried samples was performed by a semi-trained panel of judges using ten-point hedonic-scale ratings for product texture and taste were evaluated under light in a special room with individual booths. Snap was defined as the textural perception at the first bite, while crispness was perceived upon subsequent chewing. Concerning the taste, the product sourness, saltiness and bitterness was evaluated, besides popcorn-like flavour and taste of fried potato. Each of these descriptors was evaluated using a continuous line scale with five anchor points, being 0 (absent), 2.5 (slightly present), 5 (moderately present), 7.5 (strongly present) and 10 (very strongly present). The distance between the origin and the point, indicated by the panelist was measured and standardized to scores between 0 and 10 . The product acceptability was also evaluated under light, based on the taste only ("taste appraisal") and based on both product texture and taste ("overall appraisal"). For this hedonic evaluation, a similar five anchor line scale was used, ranging from zero (dislike very much), over 5 (neither like nor dislike) to 10 (like very much). Consequently, a product with a score above 5 could be considered as acceptable. Water was provided to cleanse the palate in between two tests (Mestdagh et al., 2008b).

\section{Statistical analysis}

The obtained data were statistically analyzed using General Linear Models Procedure Adapted by Statistical Package for the Social Sciences (SPSS, 1997).

\section{Results and Discussions}

\section{Chemical composition of fresh potato:}

Chemical composition of fresh potato plays an important role in the formation of the quality of potato tuber. This is because it affects of the characterise product.

The results in Table (1) show the chemical composition of fresh potato. The data show the composition of hermes potato tubers were as follows: moisture 76.86; T.S 23.14; protein 10.34; fat 1.29; ash 3.33and fiber 7.03.This results agree with (Gumul et al., 2011) who found that moisture 87.33; T.S 22.67; protein 7.82; fat 2.03; ash 4.21and fiber 9.51 .

Table 1. Chemical composition of fresh potato on dry weight basis

\begin{tabular}{lc}
\hline \multicolumn{1}{c}{ Components } & Values* \% \\
\hline Moisture \% & $\mathbf{7 6 . 8 6} \pm \mathbf{0 . 2 0 5}$ \\
Total solids \% & $\mathbf{2 3 . 1 4}$ \\
Protein \% & $\mathbf{3 . 3 1} \pm \mathbf{0 . 3 2 1}$ \\
Fat \% & $\mathbf{1 . 2 9} \pm \mathbf{0 . 2 9 2}$ \\
Ash \% & $\mathbf{2 . 3 3} \pm \mathbf{0 . 2 1 5}$ \\
Fiber \% & $\mathbf{7 . 0 3} \pm \mathbf{0 . 6 0 5}$ \\
Total Carbohydrates** & $\mathbf{8 6 . 0 4}$ \\
\hline *Value represents average of three determinations \\
** Total Carbohydrates calculated by difference
\end{tabular}

Effect of soaking on reducing sugar, aspragine and acrylamide levels in potato chips:

In potato products, levels of reducing sugars appear to have a critical influence on acrylamide formation (Oku et al., 2005 and Williams, 2005) since levels of free asparagine usually exceed those of the reducing sugars (Taeymans et al., 2004).

Formation of acrylamide in the Maillard reaction occurs via the reaction between a reducing sugar such as fructose or glucose and the amino acid asparagine at high temperatures and low water activity (Stadler $\boldsymbol{e t}$ al., 2002)

Table (4) show the effect of soaking solutions concentrations (\%) and influence of time of potato after frying on the level of reducing sugar, aspragine $(\mathrm{mg} / \mathrm{g})$ and formation of acrylamide $(\mu \mathrm{g} / \mathrm{kg})$ in potato chips during deep- fat frying. The data cleared that reducing sugars of samples soaking in $\mathrm{CaCl}_{2}$ for 60 min were significantly the lowest although samples soaking in citric acid $1 \%$ for 60 min were lowest, while the control sample highest amount of reducing sugars.

The results in the same table indicate that significant differences in asparagine contents, from control had the highest concentrations, while were lowest in treatments with $\mathrm{CaCl}_{2}$ for $60 \mathrm{~min}$ and citric acid $1 \%$ for $60 \mathrm{~min}$ respectivel in content of asparagines.

As regard to acrylamide content, it can be seen that control chips samples contained very high acrylamide content (147.66 - $151.06 \mu \mathrm{g} / \mathrm{kg}$ ) compared with those soaking in $\mathrm{CaCl}_{2}$ (49.01- 22.44 $\mu \mathrm{g} / \mathrm{kg}$ ) and soaking in citric acid $(81.05-24.73 \mu \mathrm{g} / \mathrm{kg}$ ) this may be due reduction of acrylamide by soaking in $\mathrm{CaCl}_{2}$ and citric acid. This results according with (Acar $\boldsymbol{e t}$ al., 2012) who found that used of calcium chloride it 
is possible to reduce acrylamide formation up to 7.0\%. Biedermann et al. (2002) and Gökmen et al. (2007), they found that sugar concentration has a strong correlation with the amount of acrylamide formation upon frying potatoes.

The results in the same Table (2) show that the best concentration and time of soaking for reducing of acrylamide were $\mathrm{CaCl}_{2}$ for $60 \mathrm{~min}$ and citric acid for $60 \mathrm{~min}$. This results agree with (Mestdagh et al., 2008a) who found that use the organic acids, such as citric and acetic acid to reduce the final acrylamide content, but merely due to a reduced $\mathrm{pH}$.

Calcium ions induced a supplementary acrylamide reduction, not attributed to a lower $\mathrm{pH}$. Previously, the mitigating effect at low $\mathrm{pH}$ was attributed to protonation of asparagine amino groups. This would block the nucleophilic addition of asparagine with a carbonyl compound, preventing the formation of the corresponding Schiff base, a key intermediate in the Maillard reaction and in the formation of acrylamide (Kita et al., 2004; Pedreschi et al., 2004 and Pedreschi et al., 2007). Also $\mathrm{Na}^{+}$or $\mathrm{Ca}^{2+}$ were indicated to interact with asparagine to prevent the formation of acrylamide (Park et al., 2005; Lindsay and Jang, 2005 and Gökmen and Senyuva, 2007). On the other hand, the addition of $\mathrm{NaCl}, \mathrm{CaCl}_{2}$ or citric acid might also change the oil uptake (Bunger et al., 2003; RimacBrncic et al., 2004 and Pedreschi et al., 2007).

From these results we selected the best pretreatments which reduced the acrylamide concentration and we determined the chemical composition of fried potato chips for these treatments $\left(\mathrm{cacl}_{2} 2 \%\right.$ and citric acid $1 \%$ for $60 \mathrm{~min}$ ).

Table 2. Effect of soaking on acrylamide levels in potato chips.

\begin{tabular}{|c|c|c|c|c|c|c|}
\hline \multicolumn{2}{|c|}{ Treatments } & $\begin{array}{l}\text { Time } \\
(\text { min) }\end{array}$ & $\begin{array}{c}\text { Acrylamide } \\
\text { ppm }\end{array}$ & $\begin{array}{l}\text { Reducing } \\
\text { sugar \% }\end{array}$ & Aspragine mg/g & Reduction \% \\
\hline \multirow{3}{*}{\multicolumn{2}{|c|}{ Control }} & 0 & 151.06 & 43.30 & 1.210 & - \\
\hline & & 30 & 149.21 & 43.01 & 1.200 & 1.22 \\
\hline & & 60 & 147.66 & 42.46 & 1.180 & 2.25 \\
\hline \multirow{4}{*}{$\mathrm{CaCl}_{2}$} & \multirow[b]{2}{*}{$1 \%$} & 30 & 49.01 & 42.86 & 0.889 & 67.56 \\
\hline & & 60 & 34.82 & 41.34 & 0.834 & 76.95 \\
\hline & \multirow{2}{*}{$2 \%$} & 30 & 25.6 & 39.22 & 0.644 & 83.05 \\
\hline & & 60 & 22.44 & 37.27 & 0.432 & 85.14 \\
\hline \multirow{4}{*}{$\begin{array}{l}\text { Citric } \\
\text { acid }\end{array}$} & \multirow{2}{*}{$0.5 \%$} & 30 & 81.05 & 43.21 & 0.923 & 46.34 \\
\hline & & 60 & 33.27 & 42.64 & 0.891 & 77.98 \\
\hline & \multirow{2}{*}{$1 \%$} & 30 & 36.78 & 41.87 & 0.720 & 75.65 \\
\hline & & 60 & 24.37 & 39.49 & 0.439 & 83.87 \\
\hline
\end{tabular}

Chemical composition of fried potato chips:

During deep fat frying process, product is exposed to high temperature, which affect on chemical composition and $\mathrm{pH}$ value. Therefore it is important to evaluate the changes in chemical composition and quality characteristic of the chips.

In this respect, the proximate chemical composition parameters (the percentages of moisture, T.S., protein, fat, ash, carbohydrates and $\mathrm{pH}$ ).

The results in Table (3) show the chemical composition of fresh potato, data show the composition of potato chips the moisture content were $2.85,2.15$ and 2.85 , T.S were $97.15,97.85$ and 97.15 , protein were $2.85,3.5$ and 2.5 , fat content were $36.67,26.57$ and 28.82 , ash were $2.56,3.35$ and 3.01 , total carbohydrates were 55.07, 64.25 and 62.82 and $\mathrm{pH}$ were 5.94, 5.81 and 5.31 for samples of control, $\mathrm{CaCl}_{2}$ and citric acid respectively. The data cleared that no differences were found in protein contents among all samples.

The control sample had the highest fat content. While, the potato chips soaking in $\mathrm{CaCl}_{2}$ were the lowest fat content. The differences between the chips samples in fat content may be due to soaking in $\mathrm{CaCl}_{2}$ decreased oil uptake. This result agree with (Mestdagh et al., 2008b) who found that soaking in $\mathrm{CaCl}_{2}$ reduction acrylamide formation, although decreased oil uptake. These results are similar with those reported by Kita (2002), who found that oil contents of some potato crisps varieties ranged between 35.77 to $39.44 \%$.

The results in the same table indicate that no significant differences in ash and total carbohydrates of all samples. The data shown significance differences in $\mathrm{pH}$ the control sample, while, the potato chips soaking in citric acid were the lowest pH. This data are agreed with (Mestdagh et al., 2008a) who reported that used organic acids, such as citric acid reduced the final acrylamide content, but merely due to a reduced $\mathrm{pH}$. 
Table 3. Physico - chemical composition of potato chips fried (\% on dry weight basis).

\section{Treatments}

Control $\quad \mathrm{CaCl}_{2} 2 \%$ / $60 \mathrm{~min} \quad$ Citric Acid 1\% / 60 min

Constituents

\begin{tabular}{lccc}
\hline moisture \% & $2.85 \pm 0.015$ & $2.15 \pm 0.047$ & $2.85 \pm 0.397$ \\
Total solid (T.S) \% & 97.15 & 97.85 & 97.15 \\
protein \% & $2.85 \pm 0.03$ & $3.5 \pm 0.08$ & $2.5 \pm 0.4$ \\
fat \% & $36.67 \pm 0.55$ & $26.57 \pm 0.015$ & $28.82 \pm 0.058$ \\
ash \% & $2.56 \pm 0.02$ & $3.53 \pm 0.03$ & $3.01 \pm 0.013$ \\
Total carbohydrates* \% & 55.07 & 64.25 & 62.82 \\
pH & 5.94 & 5.81 & 5.31 \\
\hline
\end{tabular}

- * Total carbohydrates calculated by difference

- Values are means of three replicates.

Physical and chemical properties of palm oil before and after frying process:

Deep-fat frying is probably one of the most dynamic processes in all of food processing. Essentially, the process involves immersing a food item in a large quantity of heated oil or fat, which is normally replenished and reused several times before being disposed. Deep-fat frying produces an product with desired sensory characteristics, including fried food flavor, golden brown color, and a crisp texture (Warner, 2004).
Extruded products and pellets are typically fried at $190-215^{\circ} \mathrm{C}$ (Gupta , 2004). This high temperature requirement and the presence of air and moisture, from the food, initiate several chemical and physical changes affecting oxidative degradation of oil used.

Some physical and chemical properties of oil used for frying process in lab were show in table (4) the data indicate that no significant differences in refractive index (RI) for palm oil, acidity, iodine number, peroxide value and Saponification value.

Table 4. Physicochemical characteristics of palm oil.

\begin{tabular}{lcccc}
\hline \multicolumn{1}{c}{ Parameters } & Fresh & $\begin{array}{c}\text { After frying } \\
\text { control }\end{array}$ & $\begin{array}{c}\text { After frying } \\
\mathbf{C a C l}_{\mathbf{2}}\end{array}$ & $\begin{array}{c}\text { After frying } \\
\text { citric acid }\end{array}$ \\
\hline Refractive index at $\mathbf{2 0}^{\mathbf{0}} \mathbf{C}$ & 1.464 & 1.464 & 1.464 & 1.465 \\
Acidity (as \% oleic acid) & 0.52 & 0.54 & 0.53 & 0.58 \\
Peroxide value (meq / $\mathbf{k g}$ oil) & 0.50 & 0.77 & 0.80 & 0.81 \\
Iodine number & 56.89 & 56.76 & 56.83 & 56.80 \\
Saponification value & 136.0 & 136.4 & 136.5 & 136.5 \\
\hline
\end{tabular}

Effect of soaking on sensory evaluation of potato chips:

Acrylamide formation in the cooked product. The Maillard reaction is also responsible for the development of colour in many cooked products via the formation of brown melanodin polymers. As a result, some authors have reported associations between instrumental colour parameters and levels of acrylamide in cooked potato products (Sharoba and Hassanien, 2014; Sharoba and Ramadan 2012; Olsson et al., 2005; Pedreschi et al., 2005 and Pedreschi et al., 2006). Therefore, instrumental colour parameters could serve as a convenient index for acrylamide levels in cooked potato products.

The sensory evaluation of control potato chips and both soaking in $\mathrm{CaCl}_{2}$ or citric acid was performed and the means of results were recorded in Table (5). The data show that the chips soaking in
$\mathrm{CaCl}_{2} 2 \%$ and citric acid $1 \%$ for $60 \mathrm{~min}$ had high scores for all characteristics compared with control chips. This may be due to decreased oil uptake, crispy texture and brighter color of chips.

This result agree with (Mestdagh et al., 2008b) who found that the addition of citric and acetic acid produced brighter coloured crisps, while $\mathrm{CaCl}_{2}$ reduction acrylamide formation, although decreased oil uptake. Also the addition of $\mathrm{CaCl}_{2}$ clearly provoked a more crispy texture.

The results in the same table indicate that soaking in citric acid show lower taste score this may be due to detected a sour taste for the crisps. This result agree with (Mestdagh et al., 2008b) who found that the addition of acids like citric acid the sensory panel detected a sour taste for the crisps in the concentration $0.025 \mathrm{M}$ of citric acid. 
Table 5. Effect of soaking on sensory evaluation potato chips.

\begin{tabular}{|c|c|c|c|c|c|c|c|c|c|c|c|c|}
\hline \multirow{2}{*}{\multicolumn{2}{|c|}{ Treatments }} & \multirow[b]{2}{*}{$\begin{array}{c}\text { Time } \\
\text { min }\end{array}$} & \multicolumn{2}{|c|}{ Texture } & \multicolumn{5}{|c|}{ Taste } & \multirow[b]{2}{*}{$\begin{array}{c}\text { Odor } \\
\text { appraisal }\end{array}$} & \multirow[b]{2}{*}{$\begin{array}{l}\text { Surface } \\
\text { colour }\end{array}$} & \multirow[b]{2}{*}{$\begin{array}{c}\text { Overall } \\
\text { appraisal }\end{array}$} \\
\hline & & & Snap & Crispness & Potato & Sour & Salt & Bitter & Popcorn & & & \\
\hline control & & $\mathbf{0}$ & $\begin{array}{c}8.10^{b} \pm \\
0.25\end{array}$ & $8.5^{a} \pm 0.21$ & $\begin{array}{c}9.75^{\mathrm{a}} \pm \\
0.48\end{array}$ & $\begin{array}{c}9.89^{\mathrm{a}} \pm \\
0.41\end{array}$ & $\begin{array}{l}9.95^{\mathrm{a}} \\
\pm 0.41\end{array}$ & $\begin{array}{c}9.13^{\mathbf{b}} \pm \\
0.11\end{array}$ & $9.79^{a} \pm 0.20$ & $8.85^{\mathrm{a}} \pm 0.41$ & $\begin{array}{c}8.93^{\mathrm{a}} \pm \\
0.65\end{array}$ & $9.25^{\mathrm{a}} \pm 0.68$ \\
\hline \multirow{4}{*}{$\mathrm{CaCl}_{2}$} & \multirow{2}{*}{$1 \%$} & 30 & $\begin{array}{c}6.91^{c} \pm \\
0.25\end{array}$ & $7.5^{b} \pm 0.20$ & $\begin{array}{c}8.50^{\mathbf{b}} \pm \\
0.30\end{array}$ & $\begin{array}{c}9.97^{\mathrm{a}} \pm \\
0.15\end{array}$ & $\begin{array}{l}9.55^{\mathrm{a}} \\
\pm 0.25\end{array}$ & $\begin{array}{c}9.91^{\mathrm{a}} \pm \\
0.15\end{array}$ & $9.83^{\mathrm{a}} \pm 0.21$ & $7.87^{b} \pm 0.25$ & $\begin{array}{c}8.65^{\mathrm{a}} \pm \\
0.58\end{array}$ & $8.85^{\mathrm{a}} \pm 0.58$ \\
\hline & & 60 & $\begin{array}{c}7.12^{c} \pm \\
0.15\end{array}$ & $7.87^{b} \pm 0.25$ & $\begin{array}{c}8.45^{\mathbf{b}} \pm \\
0.51\end{array}$ & $\begin{array}{c}9.95^{\mathrm{a}} \pm \\
0.15\end{array}$ & $\begin{array}{l}9.61^{\mathrm{a}} \\
\pm 0.18\end{array}$ & $\begin{array}{c}9.92^{\mathrm{a}} \pm \\
0.15\end{array}$ & $9.64^{\mathrm{a}} \pm 0.28$ & $7.75^{b} \pm 0.18$ & $\begin{array}{c}8.68^{\mathrm{a}} \pm \\
0.29\end{array}$ & $8.87^{\mathrm{a}} \pm 0.25$ \\
\hline & \multirow{2}{*}{$2 \%$} & 30 & $\begin{array}{c}8.43^{b} \pm \\
0.15\end{array}$ & $8.53^{a} \pm 0.15$ & $\begin{array}{c}8.88^{\mathbf{b}} \pm \\
0.14\end{array}$ & $\begin{array}{c}9.88^{\mathrm{a}} \pm \\
0.25\end{array}$ & $\begin{array}{l}8.67^{b} \\
\pm 0.15\end{array}$ & $\begin{array}{c}9.91^{\mathrm{a}} \pm \\
0.18\end{array}$ & $9.61^{\mathrm{a}} \pm 0.15$ & $7.80^{b} \pm 0.15$ & $\begin{array}{c}8.88^{\mathrm{a}} \pm \\
0.28\end{array}$ & $8.50^{\mathrm{a}} \pm 0.40$ \\
\hline & & 60 & $\begin{array}{c}9.13^{a} \pm \\
0.14\end{array}$ & $9.22^{a} \pm 0.24$ & $\begin{array}{c}8.50^{b} \pm \\
0.10\end{array}$ & $\begin{array}{c}9.84^{a} \pm \\
0.15\end{array}$ & $\begin{array}{l}8.75^{b} \\
\pm 0.18\end{array}$ & $\begin{array}{l}9.91^{\mathrm{a}} \pm \\
0.15\end{array}$ & $9.22^{a} \pm 0.20$ & $8.75^{a} \pm 0.18$ & $\begin{array}{c}9.38^{\mathrm{a}} \pm \\
0.15\end{array}$ & $8.88^{a} \pm 0.15$ \\
\hline \multirow{4}{*}{ Citric acid } & \multirow{2}{*}{$0.5 \%$} & 30 & $\begin{array}{c}6.29^{\mathrm{d}} \pm \\
0.30\end{array}$ & $7.50^{b} \pm 0.25$ & $\begin{array}{c}8.62^{b} \pm \\
0.29\end{array}$ & $\begin{array}{c}8.95^{\mathbf{b}} \pm \\
0.35\end{array}$ & $\begin{array}{l}9.72^{a} \\
\pm 0.30\end{array}$ & $\begin{array}{c}9.10^{\mathrm{b}} \pm \\
0.15\end{array}$ & $9.84^{\mathrm{a}} \pm 0.18$ & $7.50^{b} \pm 0.30$ & $\begin{array}{c}8.63^{\mathbf{b}} \pm \\
0.29\end{array}$ & $8.73^{a} \pm 0.45$ \\
\hline & & 60 & $\begin{array}{c}6.77^{c} \pm \\
0.20\end{array}$ & $8.00^{b} \pm 0.15$ & $\begin{array}{c}8.63^{b} \pm \\
0.19\end{array}$ & $\begin{array}{c}8.38^{\mathbf{b}} \pm \\
0.27\end{array}$ & $\begin{array}{l}9.56^{\mathrm{a}} \\
\pm 0.17\end{array}$ & $\begin{array}{c}9.12^{\mathbf{b}} \pm \\
0.1\end{array}$ & $9.86^{\mathrm{a}} \pm 0.10$ & $6.75^{c} \pm 0.17$ & $\begin{array}{c}8.87^{\mathrm{a}} \pm \\
0.15\end{array}$ & $8.65^{a} \pm 0.38$ \\
\hline & \multirow{2}{*}{$1 \%$} & 30 & $\begin{array}{c}7.24^{c} \pm \\
0.20\end{array}$ & $7.20^{b} \pm 0.25$ & $\begin{array}{c}8.62^{b} \pm \\
0.09\end{array}$ & $\begin{array}{c}7.97^{\mathrm{c}} \pm \\
0.17^{-1}\end{array}$ & $\begin{array}{l}9.65^{\mathrm{a}} \\
\pm 0.35\end{array}$ & $\begin{array}{c}8.64^{b} \pm \\
0.15\end{array}$ & $9.64^{\mathrm{a}} \pm 0.21$ & $6.68^{c} \pm 0.17$ & $\begin{array}{c}8.69^{\mathrm{a}} \pm \\
0.29\end{array}$ & $8.50^{\mathrm{a}} \pm 0.51$ \\
\hline & & 60 & $\begin{array}{c}7.75^{b} \pm \\
0.28\end{array}$ & $7.44^{b} \pm 0.20$ & $\begin{array}{l}8.73^{b} \pm \\
0.15\end{array}$ & $\begin{array}{c}7.65^{c} \pm \\
0.30\end{array}$ & $\begin{array}{l}8.92^{b} \\
\pm 0.40\end{array}$ & $\begin{array}{c}8.55^{b} \pm \\
0.13\end{array}$ & $9.55^{\mathrm{a}} \pm 0.25$ & $7.30^{b} \pm 0.41$ & $\begin{array}{c}8.63^{b} \pm \\
0.19\end{array}$ & $8.75^{a} \pm 0.37$ \\
\hline$* \mathbf{L S D}$ & & & 0.80 & 0.85 & 0.82 & 0.78 & 0.74 & 0.75 & 0.80 & 0.81 & 0.83 & 1.06 \\
\hline
\end{tabular}

- *LSD =least significant difference at 0.05 .

- Values are means of evaluations. Means of evaluations having the same letter(s) within a column are not significantly different $(\mathrm{P}>0.05)$. 
While, addition of citric and acetic acid produced brighter coloured crisps. This result agree with (Mestdagh et al., 2008b).

The relation of the results in Table (2) and these of Table (5), it can be seen that the effect of sensory characteristics on acrylamide formation is very slight comparing with frying conditions such as time and temperature of frying which have important role in acrylamide formation Obtained results are in agreement with those reported by (Granda $\boldsymbol{e t}$ al., 2005), who reported that color could not be used as an indication of acrylamide content because potato chips with similar color had very different acrylamide concentrations. In addition, (Taubert $\boldsymbol{e t}$ al., 2004) found that at a level of browning 2 "golden brown", acrylamide content varied from 2.5 to 13 ppm in 3-mm slices potatoes and ranged from 4 to 18 $\mathrm{ppm}$ in grated potatoes.

They reported that because color continues to develop during the Maillard reaction, and acrylamide may start degrading, browning alone should not be used as the sole predictor of acrylamide formation. In contrast, Stadler et al. (2002), Zyzak et al. (2003) and Becalski et al. (2003) reported that the formation of acrylamide in foods is closely linked to the formation of desirable characteristics such as flavor and color. Because the Maillard reaction is favored by conditions of high temperature, resulting in the flavors and brown color in roasted, baked and fried foods.

\section{Conclusion}

It recommended that soaking of potato before frying in $\mathrm{CaCl}_{2} 2 \%$ or citric acid $1 \%$ for 60 min (as possible as) are important to reduce acrylamide formation during frying. Soaking in $\mathrm{CaCl}_{2} 2 \%$ for $60 \mathrm{~min}$ it is possible to reduce acrylamide formation up to $85 \%$, although decreased oil uptake. Also the addition of $\mathrm{CaCl}_{2}$ clearly provoked a more crispy texture.

Soaking in citric acid $1 \%$ for $60 \mathrm{~min}$ it is possible to reduce acrylamide formation up to $83 \%$, although produced brighter colour crisps.

\section{References}

Acar, O. C., Pollio M., Monaco R. D., Fogliano V. and Gokmen V. (2012) Effect of Calcium on Acrylamide Level and Sensory Properties of Cookies.Food Bioprocess Technol (2012) 5:519-526.

Allan, S. (2002) Acrylamide angst, another annoying distraction about food safety. (Electronic version). Agrochemical and Environmental News Issue,October,No.198.from: http:/www.envirofacs.org/Acrylamide\%20An gst.pdf.

Amrein, T., Bachmann, S., Noti, A., Biedermann, M., Ferraz, M., Biedermann, S., Grob, K., Keiser, A., Realini, P., Escher, F. and
Amado, R. (2003) Potential of acrylamide formation, sugars and free asparagine in potatoes: a comparison of cultivars and farming systems. J Agric Food Chem 51:5556-5560.

A.O.A.C. (2000) Association of Official Method of Analysis. Official Analytical Chemists. 17th Ed., Gaithersburg, MD: AOAC International. (Official Method 925.10, 920.87).

A.O.A.C. (2005) Official methods of analysis, 18th Ed. Association of Official Analytical Chemists, Ins. U.S.A.

Becalski, A.; Lau, B. P.; Lewis, D. and Seaman, S.W., (2003) Acrylamide in foods: occurrence, sources and modeling, J. Agric. Food Chem., 51:802-808.

Besaratinia, A. and Pfeifer, G. (2007) A review of mechanisms of acrylamide carcinogenicity. Carcinogenesis, 28(3):519-528.

Biedermann, M., Noti, A., Biedermann-Brem, S., Mozzetti, V. and Grob, K. (2002) Experiments on acrylamide formation and possibilities to decrease the potential of acrylamide formation in potatoes. Mitt. Geb. Lebensm Unters Hyg; 93:668-687.

Bunger, A., Moyano, P., and Rioseco, V. (2003) $\mathrm{NaCl}$ soaking treatment for improving the quality of french-fried potatoes. Food Research International, 36, 161-166.

Burch, R. (2007) Examination of the effect of domestic cooking on acrylamide levels in food. Final Report for Food Standards Agency. Pp.4.

Glese, J. (2002) Acrylamide in foods. Food technol., 56(10):71-72.

Gökmen, V., and Senyuva, H. Z. (2007) Acrylamide formation is prevented by divalent cations during the Maillard reaction. Food Chemistry, 103, 196-203.

Gökmen, V., Akbudak, B., Serpen, A., Acar, J., Turan, Z. and Eri, A. (2007) Effects of controlled atmosphere storage and low-dose irradiation on potato tuber components affecting acrylamide and color formations upon frying. Eur. Food Res. Technol; 224:681-7.

Granda, C., Moreira, R. G. and Castell-Perez, E. (2005) Effect of raw potato composition on acrylamide formation in potato chips. $\mathrm{J}$ of Food Sci., 70(9):519-525.

Gumul D., Ziobro R., Noga M.and Sabat R. (2011) Charactrisation of five potato cultivars according to their nutritional and pro-health components. Acta Sci. Pol., Technol. Aliment. 10(1), 73-81.

Gupta, M. J. (2004) The effect of oil processing on frying oil stability. In: Gupta MK, Warner K, White PJ (eds) Frying technology and practice. AOCS, Champaign, pp 76-90. 
Hogervorst, J.G., Schouten, L.J., Konings, E.J., Goldbohm, R.A. and van den Brandt, P.A. (2008) Dietary acrylamide intake and the risk of renal cell, bladder, and prostate cancer. Am. J. Clin. Nutr.; 87(5): 1428-1438.

Hogervorst, J.G.F., Schouten, L.J., Konings, E.J.M., Goldbohm, R.A. and van den Brandt, P.A. (2009a) Lung cancer risk in relation to dietary acrylamide intake. Journal of the National Cancer Institute, 101: 651-662.

Hogervorst, J.G.F., Schouten, L.J., Konings, E.J.M., Goldbohm, R.A. and van denBrandt, P. A. (2009b) Dietary acrylamide intake and brain cancer risk. Cancer Epidemiology Biomarkers and Prevention, 18: 1663-1666.

International Agency for Research on Cancer, (IARC) (1994) Some industrial chemicals. Monographs on the evaluation of the carcinogenic risk of chemicals to humans, Vol. 60 (Lyon: IARC), pp. 389-433.

Kim, C. T., Hwang, E. S. and Lee, H. J. (2005) Reducing acrylamide in fried snack products by adding amino acids. J. of Food Sci., 70(5):354-358.

Kita, A. (2002) The influence of potato chemical composition on crisp texture. Food Chemistry, 76:173-179.

Kita, A., Brathen, E., Knutsen, S. H., and Wicklund, T. (2004) Effective ways of decreasing acrylamide content in potato crisps during processing. Journal of Agricultural and Food Chemistry, 52, 7011-7016.

Lindsay, R. (2002) Acrylamide review. (Electronic version) from http://www.inchem.org/documents/pims/chem ical/pim652.htm

Lindsay, R. C., and Jang, S. J. (2005) Chemical intervention strategies for substantial suppression of acrylamide formation in fried potato products. In M. Friedman \& D. Mottram (Eds.), Chemistry and Safety of Acrylamide in Food (pp. 393-404). New York: Springer.

Mestdagh, F., Maertens, J., Cucu, T., Delporte, K., Van Peteghem, C. \& De Meulenaer, B. (2008a). Impact of additives to lower the formation of acrylamide in a potato model system through $\mathrm{pH}$ reduction and other mechanisms. Food Chemistry, 107, 26-31.

Mestdagh, F., Wilde, D., Delporte T., Peteghem K. V. and Meulenaer C., D. (2008b) Impact of chemical pre-treatments on the acrylamide formation and sensorial quality of potato crisps. Food Chemistry, 106, 914-922

Mottram, D. S.; Wedzicha, B. L. and Dodson, A. T. (2002) Acrylamide is formed in the Maillard reaction. Nature 419:448-449.

Mucci, L.A., Dickman, P.W., Steineck, G., Adami, H.O. and Augustsson, K. (2003) Dietary acrylamide and cancer of the large bowel, kidney, and bladder: Absence of an association in a population-based study in Sweden. British Journal of Cancer, 88(1): 8489.

Oku, K., Kurose, M., Ogawa, T., Kubota, M., Chaen, H. and Fukuda, S., (2005) Suppressive effect of trehalose on acrylamide formation from asparagine and reducing saccharides. Bioscience Biotechnology and Biochemistry, 69(8), 1520-1526.

Olsson, K., Svensson, R. and Roslund, C. (2004) Tuber components affecting acrylamide formation and color in fried potato: variation by variety, year, storage temperature and storage time. J Sci Food Agric 84:447-458.

Olesen, P.T., Olsen, A., Frandsen, H., Frederiksen, K., Overvad, K. and Tjonneland, A. (2008) Acrylamide exposure and incidence of breast cancer among postmenopausal women in the Danish diet, cancer and health study. International Journal of Cancer, 122(9): 2094-2100.

Park, Y. W., Yang, H. W., Storkson, J. M., Albright, K. J., Liu, W. and Lindsay, R. C., (2005) Controlling acrylamide in french fry and potato chip models and a mathematical model of acrylamide formation - Acrylamide: Acidulants, phytate and calcium. In M. Friedman \& D. Mottram (Eds.), Chemistry and safety of acrylamide in food (pp. 343356). New York: Springer.

Pedreschi, F., Bustos, O., Mery, D., Moyano, P., Kaack, K., and Granby, K. (2007) Color kinetics and acrylamide formation in $\mathrm{NaCl}$ soaked potato chips. Journal of Food Engineering, 79, 989-997.

Pedreschi, F., Kaack, K., and Granby, K. (2006) Acrylamide content and color development in fried potato strips. Food Research International, 39(1), 40-46.

Pedreschi, F., Kaack, K., and Granby, K. (2004) Reduction of acrylamide formation in potato slices during frying. LWT - Food Science and Technology, 37, 679-685.

Pedreschi, F., Moyano, P., Kaack, K., and Granby, K. (2005) Color changes and acrylamide formation in fried potato slices. Food Research International , 38(1), 1-9.

Rimac-Brncic, S., Lelas, V., Rade, D., and Simundic, B. (2004) Decreasing of oil absorption in potato strips during deep fat frying. Journal of Food Engineering, 64, 237241.

Sharoba A. M. and Hassanien M. F. R. (2014) Rheological characteristics of vegetable oils as affected by deep frying of French fries.Journal of food measurement and characterization; 8 (3) : 171-179. 
Sharoba A. M. and Ramadan M. F. (2012) Impact of frying on faty acid profile and rheological behavior of some vegetable oils. Journal of food processing and technology, 3, 7, 161. http:// dx.doi.org/10.4172/21577110.1000161.

Stadler, R., Blank, I.; Varga, N., Robert, F., Hau, J., Guy, P., Robert, P. and Riediker, S. (2002) Acrylamide from Maillard reaction products. Nature 419:449.

Stadler, R. H., Robert, F., Riediker, S., Varga, N., Davidek, T., Devaud, S., et al. (2004) Indepth mechanistic study on the formation of acrylamide and other vinylogous compounds by the Maillard reaction. Journal of Agricultural and Food Chemistry, 52, 55505558.

Statistical Package for the Social Sciences, SPSS (1997) SPSS based 7.5 for windows, User's Guide; SPSS inc.

Swedish National Food Administration (2002) Information about acrylamide in food [http://www.slv.se/engdefault.asp].

Taeymans, D., Wood, J., Ashby, P., Blank, I., Studer, A., Stadler, R. H., Gonde, P., Van Eijck, P., Lalljie, S.; Lingnert, H., Lindblom, M., Matissek, R., Muller, D., Tallmadge, D., O'Brien, J., Thompson, S., Silvani, D. and Whitmore, T. (2004) A review of acrylamide: an industry perspective on research, analysis, formation, and control. Crit. Rev. Food Sci. Nutr., 44:323-347.

Tareke, E., Rydberg, P., Karlsson, S., Eriksson, S. and Törnqvist, M. (2002). Analysis of acrylamide, a carcinogen formed in heated foodstuffs. J Agric Food Chem; 50:49985006.

Taubert, D., Harlfinger, S., Henkes, L., Berkels, R., and Schoemig, E. (2004) Influence of processing parameters on acrylamide formation during frying of potatoes. Journal of Agricultural and Food Chemistry, 52, 27352739.

Vattem, D. A. and Shetty, K. (2003) Acrylamide in food: a model for mechanism of formation and its reduction. Innovative Food Science and Emerging Technologies 4, 331-338.

Warner, K. (2004) Chemical and physical reactions in oil during frying. In: Gupta, M.K.; Warner. K. and White, P.J. (eds) Frying technology and practice. AOCS, Champaign, pp 16-28.

Wicklund, T., Ostlie, H. Lothe, O., Knutsen, S., Brathen, E. and Kita, A. (2006) Acrylamide in potato crisp - the effect of raw material and processing, Lebensmittel-Wissenschaft-undTechnologie 39:571-575.

Williams, J. S. E. (2005). Influence of variety and processing conditions on acrylamide levels in fried potato crisps. Food Chemistry, 90(4), 875-881.

Wilson, K.M., Giovannucci, E., Stampfer, M.J. and Mucci, L.A. (2012) Dietary acrylamide and risk of prostate cancer. International Journal of Cancer, 131 (2): 479- 487.

Yusa, V., Quintas, G., Pardo, O., Marti, P. and Pastor, A. (2006) Determination of acrylamide in foods by pressurized fluid extraction and liquid chromatography tandem mass spectrometry used for a survey of Spanish cereal-based foods. Food Additives and Contaminants. 23, 237-244.

Zyzak, D. V., Sanders, R. A., Stojanovic, M., Tallmadge, D. H., Eberhart, B. L., Ewald, D. K., Gruber, D. C., Morsch, T. R., Strothers, M. A., Rizzi, G. P. and Villagran, M. D. (2003) Acrylamide formation mechanism in heated foods. J. Agric. Food Chem. 51:4782-4787. 


\section{دراسة تأثير بعض المعاملات على خفض نسبه الاكريلاميد في البطاطس الثيبسي}

حسن حسن على خلف ، اشرف مهذى شرويه ، احمد ابراهيم الاسوقى ، خالا رجائي عبدريه البسيونى"، السيد محمد عفيفى" .

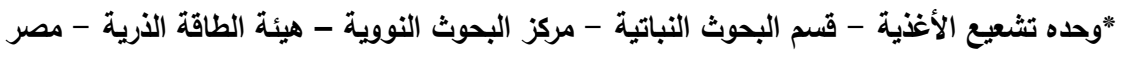

قسم علوم الأغذية - كلية الزراعة - جامعة بنها - مصر.

أجريت هذه الدراسة بهدف دراسة نأثير معاملات النقع في محلول من كلوريد الكالسيوم وحامض الستريك بنركيزات ( 0.5 و و 1 و و 1.5 و 1.5

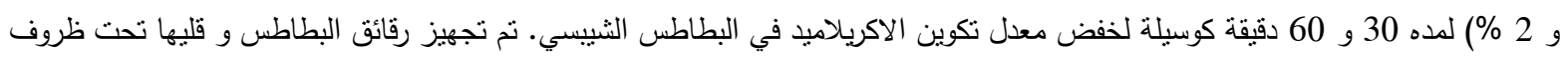

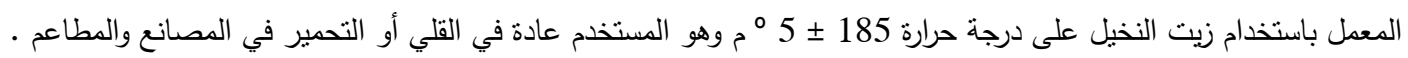
حيث أظهرت النتائج أن:-

- عدم وجود اختلافات ملحوظة في التركيب الكيماوي للبطاطس الثيبيسى تحت الدراسة ولكن كانت المعاملة بالنقع في كلوريد الكالسيوم بتركيز

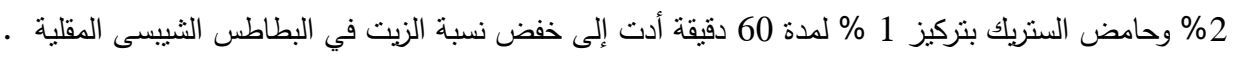

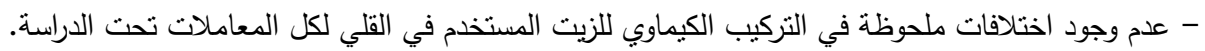

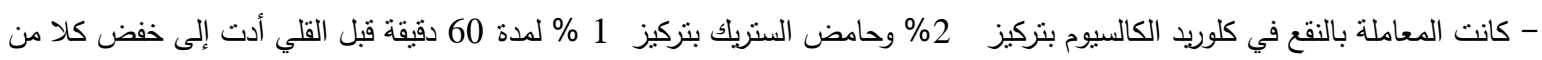

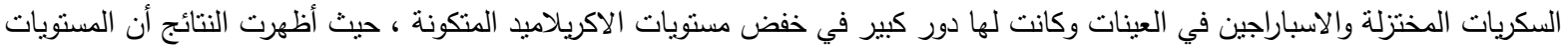

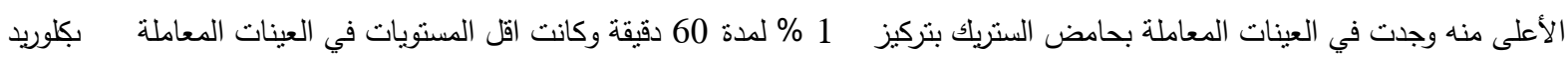

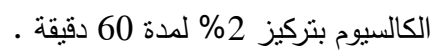
- كما وجد أن الخواص العضوية الحسية لا تعتبر مؤشرا لمحتوى الاكريلاميد في العينات حيث وجد أن العينات التي لها خواص حسية متقاربة

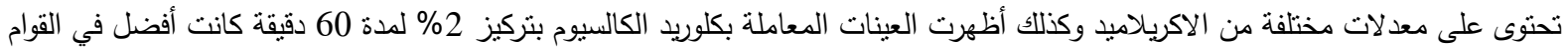

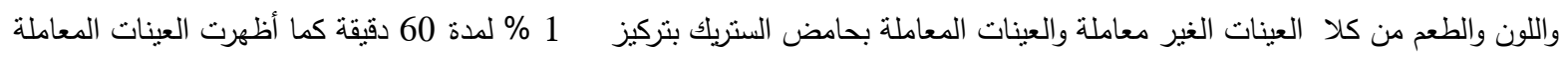
بحامض الستريك بتركيز 1 \% لددة 60 دقيقة تحسن في اللون بالمقارنة بباقي العينات. 